\title{
Information Technology Efforts Against COVID-19: A Review of Open Source Projects
}

\author{
Nazila Moftian 1(D), Peyman Rezaei Hachesu 1 (D), Taha Samad-Soltani 2* iD \\ 1. Student Research Committee, Tabriz University of Medical Sciences, Tabriz, Iran \\ 2. Iranian Center of Excellence in Health Management School of Management and Medical Informatics, Tabriz University \\ of Medical Sciences, Tabriz, Iran
}

\begin{tabular}{c}
\hline Article Info \\
\hline doi 10.30699/jambs.29.132.1 \\
\hline Received: $2020 / 05 / 27 ;$ \\
Accepted: $2020 / 09 / 24 ;$ \\
Published Online: 03 Jan 2021 \\
\hline Use your device to scan and read the \\
article online \\
Q \\
(1)
\end{tabular}

Corresponding Information: Taha Samad-Soltani,

Iranian Center of Excellence in Health Management School of Management and Medical Informatics, Tabriz University of Medical Sciences, Tabriz, Iran

E-Mail:

samadsoltani@,tbzmed.ac.ir

\begin{abstract}
Currently, efforts have focused on dealing with the emerging coronavirus disease 2019 (COVID-19) worldwide. Hopefully, information technology can be applied to meet the challenges related to the pandemic and biosurveillance. Free and opensource software (FOSS) model has emerged as an effective tool against these challenges. The main objective of this study was to determine and summarize the application of FOSS in published and released resources and materials against COVID-19. This review includes projects that were available through GitHub and SourceForge reliable web-based materials. All projects were identified between January 1 and April 10, 2020. Search terms in GitHub and SourceForge were based on clinical terminologies, such as COVID-19, COVID, Covid19, and Corona Virus. Inclusion or exclusion criteria were used to filter the results. Finally, a screening procedure was followed to achieve the most related records. We identified 46,426 records in GitHub and seven projects in SourceForge. The top 40 projects were included. The results show that a high percentage of FOSS projects against COVID19 were related to visual dashboards. The open dataset and analytical methods made a significant contribution to this context. Previously learned lessons from FOSS have shown that the explained projects would play important roles in future epidemics by forking and joining in new projects, which formed around a specific problem.
\end{abstract}

Keywords: COVID-19, Coronavirus, Free and open source software, FOSS

Copyright $(\mathcal{C} 2021$, This is an original open-access article distributed under the terms of the Creative Commons Attribution-noncommercial 4.0 International License which permits
copy and redistribution of the material just in noncommercial usages with proper citation.

\section{Introduction}

The disease caused by the novel coronavirus (COVID19) was first observed in December 2019 in Wuhan, China. COVID-19 is considered to be transmitted by respiratory droplets and direct contact. By May 27, 2020, a total of 5,718,885 infected cases had been confirmed, affecting 215 countries and territories globally $(1,2)$. Now, worldwide efforts are focusing on dealing with the emerging COVID-19 pandemic. To accelerate scientific efforts and overcome the challenges of current and future health threats, it is necessary to use information technology (IT)-related data and analytics capabilities (3). Recent advancements in health IT are completely improving the potential to identify and detect unpredicted disease outbreaks and pandemics. Hopefully, IT can be applied to meet challenges related to the disease and biosurveillance (4). However, researchers have mentioned during the COVID-19 crisis that any global health disasters are also information disasters that require more attention in the IT field (5). For example, in an infectious disease outbreak, gathering, sharing, and analyzing accurate and real-time data about cases with the disease and their additional information are important for effective and evidencebased interventions (6). To master the soaring demand for an agile response, epidemic events always require instant information generation, exchange, and analysis involving strong cooperation between various stakeholders. Collaborative IT is the main actor in this context. Social networks, as well as computational, visualization, and sharing platforms, are useful and accessible technologies in difficult times. In healthcarerelated recovery endeavors, free and open-source software (FOSS) systems have emerged as an effective tool against these challenges for cross-sectional or organizational applications (7).

Many FOSS platforms were developed in previous epidemic events and disasters. The researchers stated five valuable features of FOSS in health informatics efforts, namely no access discrimination, trust and transparency, low cost and local capacity, shared interorganizational development, and adaptability. FOSS eliminates download limitations and is widely 
available for health activists around the world. Also, the development mechanism in FOSS is clear and trustworthy with global team collaboration. Therefore, FOSS is resistant to any political and economic events. FOSS helps reduce digitalization costs because there is no additional cost for the product design and development. To maintain the software, local and national capacity can be engaged by health policymakers. Additionally, all organizations, including non-governmental organizations (NGOs) and humanitarian relief groups, need informatics tools to be efficient. But most of these organizations do not have the budget required to purchase expensive commercial software. Health FOSS can be designed and implemented globally when a disaster like COVID-19 strikes. The last advantage is adaptability. Countries have different approaches to handling quick responses in a health disaster. With FOSS, any country can modify and customize it to suit its own national priorities (8). Studies on other epidemics, such as Ebola $(9,10)$ or severe acute respiratory syndrome (SARS) (11) have shown that opensource software was able to support in the fight against one of the most lethal pandemics of recent days, and it can likely be used in the COVID-19 situation. Using opensource products can save a lot of time and money, and so it can be essential for global organizations (12).

According to the importance of the unified and integrated approaches to handle epidemic disasters by applying FOSS potential, this paper presents a review of recent open-source efforts and products against the COVID-19 pandemic. The main objective of our study was to determine and summarize the application of FOSS in published and released resources and materials against COVID-19.

\section{Materials and Methods}

\section{Inclusion criteria}

This review included projects that were available through GitHub, SourceForge, and Google Scholar recently indexed materials. Projects were included if they: (i) were released or published in 2020 (ii), focused on COVID-19 or related topics (iii), were in English or translatable, and (iv) had a repository that consisted of source codes and detailed descriptions. Projects without any information about the aims and applications against COVID-19 were removed.

\section{Search Strategy}

The study sample was identified through systematic searches in GitHub, SourceForge, and Google Scholar. All projects were identified between January 1 and April 10, 2020. Two reviewers (TSS, PR) screened the apps at the same time. Search terms in GitHub and SourceForge were based on clinical terminologies, such as COVID19, COVID, Covid19, and Corona Virus.

\section{Screening Procedure}

Since the screening procedure for GitHub was different from that of SourceForge, the screening procedures were reported separately. In GitHub, the projects were included for review if they had more than 300 stargazers or had been forked more than 300 times or continuously updated. In SourceForge, projects with more than 10 downloads in the last week (updated less than one month ago) were included. Figure 1 provides an overview of the selection process.

\section{Results}

The reviewers detected 46,426 projects in GitHub and seven projects in SourceForge. The inclusion and exclusion criteria were applied to the results. Finally, 40 projects were chosen for qualitative analysis (Figure 1).

A total of 40 projects were identified (GitHub $=38$, SourceForge $=2$ ) as active and growing. Table 1 shows a summary of FOSS projects. The mean number of stargazers per software in GitHub was $1.44 \mathrm{k}$ (range 61$20.2 \mathrm{k}$ ), and the mean software forks rating was 616.26 (range 25-10.9k). The mean number of downloads in the last week in SourceForge was 47. Also, out of 40 software programs, 13 had the MIT License, and 57.5\% of the stakeholders were volunteers. Most of the software packages have been designed for researchers, public health institutes and organizations, and the atrisk population to apply a usable tool to track the COVID-19 outbreak. They allow users to visualize prevalence estimates on a world map and compare estimates between regions, population groups, and modes of testing. The software data allows the user to generate evidence for planning, modeling, and epidemiological studies. Also, key considerations in combating the COVID-19 outbreak, such as when and how to enhance tracking, response efforts, and resource distribution are offered.

Twenty-eight GitHub software programs were categorized as follows: Business Intelligence and Visual Dashboards (23.68\%), Time-Series (13.15\%), Artificial Intelligence $(10.52 \%)$, Epidemiological Approaches $(10.52 \%)$, Web Services (21.05\%), etc. 

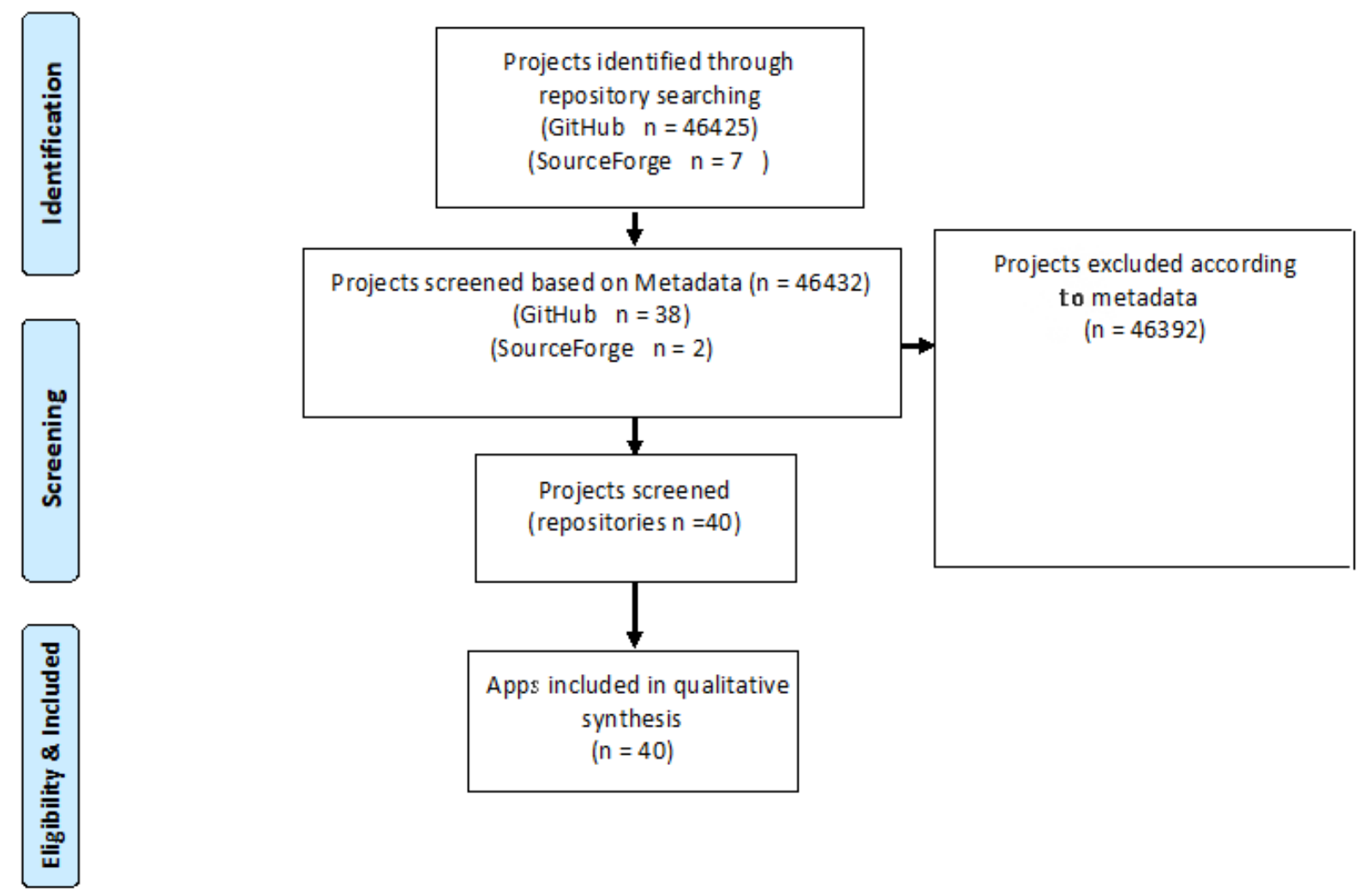

Figure 1. The selection flow diagram of FOSS projects 
Table 1. Summary of top FOSS projects against COVID-19

\begin{tabular}{|c|c|c|c|c|c|c|c|c|c|c|c|}
\hline & & Title & $\begin{array}{c}\text { Star } \\
\text { gazer }\end{array}$ & $\begin{array}{c}\text { Last } \\
\text { Update }\end{array}$ & Languages and technologies & Forks & $\begin{array}{c}\text { Licen } \\
\text { se }\end{array}$ & Desc & Aims & Country & $\begin{array}{c}\text { Stakeh } \\
\text { olders }\end{array}$ \\
\hline \multirow{7}{*}{\multicolumn{2}{|c|}{ 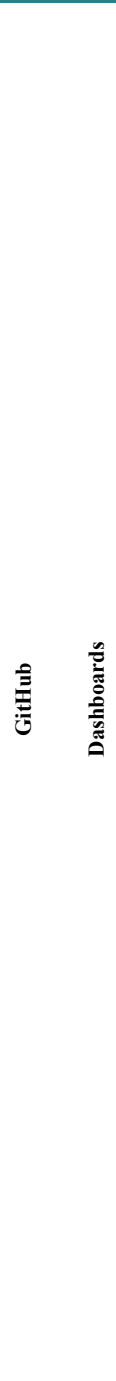 }} & $\frac{\underline{\text { CSSEGISa }}}{\underline{\text { ndData/CO }}}$ & $20.2 \mathrm{k}$ & $\begin{array}{l}\text { less than } \\
1 \text { day }\end{array}$ & $\begin{array}{l}\text { visual dashboard } \\
\text { ArcGIS } \\
\text { Multi-Source } \\
\text { Live-Stream } \\
\text { Open dataset }\end{array}$ & $10.9 \mathrm{k}$ & . & $\begin{array}{l}\text { Data repository for the COVID-19 Visual } \\
\text { Dashboard. }\end{array}$ & $\begin{array}{l}\text { The digital dashboard reports COVID-19 cases at the governmental } \\
\text { divisions in China at province level and at city level in the some countries } \\
\text { such as the United States, Australia and Canada, and at the country level } \\
\text { otherwise. }\end{array}$ & 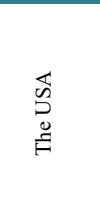 & 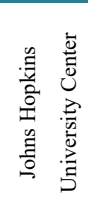 \\
\hline & & $\begin{array}{l}\begin{array}{c}\text { tokyo- } \\
\text { metropolita }\end{array} \\
\underline{\mathrm{n}-} \\
\frac{\text { gov/covid1 }}{\underline{9}}\end{array}$ & $5.3 \mathrm{k}$ & $\begin{array}{l}\text { less than } \\
1 \text { day }\end{array}$ & $\begin{array}{l}\text { Visual Dashboard } \\
\text { Vue } \\
\text { HTML } \\
\text { Open dataset }\end{array}$ & $1.7 \mathrm{k}$ & 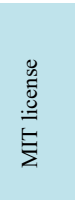 & Tokyo COVID-19 Task Force website & $\begin{array}{l}\text { Provide real-time information to Tokyo residents, companies with offices } \\
\text { in Tokyo, and tourists to Tokyo to understand the current situation of } \\
\text { COVID-19 based on statistics. }\end{array}$ & 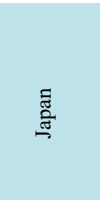 & 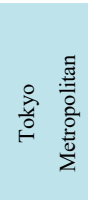 \\
\hline & & $\frac{\frac{\text { covid19indi }}{\text { a/covid19in }}}{\underline{\text { dia-react }}}$ & $2.1 \mathrm{k}$ & $\begin{array}{l}\text { less than } \\
1 \text { day }\end{array}$ & $\begin{array}{l}\text { Visual Dashboard } \\
\text { JavaScript } \\
\text { Open dataset }\end{array}$ & $1.3 \mathrm{k}$ & 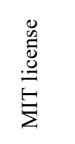 & Visual dashboard and data repository & State based up to date reporting of Corona cases & 蔫 & 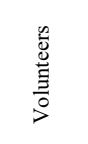 \\
\hline & & $\frac{\begin{array}{c}\mathrm{pcm}- \\
\mathrm{dpc} / \mathrm{COVI}\end{array}}{\underline{\mathrm{D}-19}}$ & $3.1 \mathrm{k}$ & $\begin{array}{l}\text { less than } \\
1 \text { day }\end{array}$ & $\begin{array}{l}\text { Visual Dashboard } \\
\text { Interactive Geographical } \\
\text { dashboard } \\
\text { Open dataset } \\
\text { ArcGIS }\end{array}$ & $1.5 \mathrm{k}$ & . & $\begin{array}{l}\text { The information updated daily at 18:30 (after the } \\
\text { Head of Department press }\end{array}$ & $\begin{array}{l}\text { To inform citizens and make the collected data available, useful only for } \\
\text { communication and information purposes }\end{array}$ & 吝 & 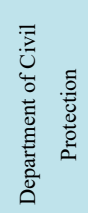 \\
\hline & & $\begin{array}{l}\frac{\text { someshkar/ }}{\text { covid19indi }} \\
\underline{\text { a-cluster }}\end{array}$ & 988 & $\begin{array}{l}\text { less than } \\
1 \text { day }\end{array}$ & $\begin{array}{l}\text { Visual Network Dashboard } \\
\text { Graph analysis and Network } \\
\text { Clustering } \\
\text { NLP Extraction From } \\
\text { Unstructured Notes } \\
\text { Javascript }\end{array}$ & 670 & 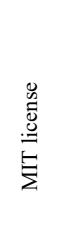 & $\begin{array}{l}\text { The primary data source is collected by volunteers } \\
\text {, a crowdsourced database collated from various } \\
\text { news as well as government sources }\end{array}$ & $\begin{array}{l}\text { To track geographic transmission COVID19 in India open up options for } \\
\text { analysis for policy/decision makers so that they can be more strategic in } \\
\text { testing cases and deploying resources like ventilators, beds \& medicines. }\end{array}$ & 苞 & 总 \\
\hline & & $\begin{array}{l}\text { github/covi } \\
\stackrel{\mathrm{d} 19-}{\text { dashboard }} \\
\end{array}$ & 795 & $\begin{array}{l}\text { less than } \\
1 \text { day }\end{array}$ & $\begin{array}{l}\text { Visual Dashboards } \\
\text { Jupyter notebook } \\
\text { Fastpage }\end{array}$ & 229 & 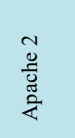 & $\begin{array}{l}\text { A website that visualize up to date COVID-19 } \\
\text { statistics, powered by fast pages }\end{array}$ & $\begin{array}{l}\text { Gather data, make visualizations and perform analysis regarding the } \\
\text { COVID-19 epidemic. }\end{array}$ & 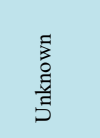 & 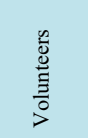 \\
\hline & & $\frac{\underline{\text { kaz- }}}{\frac{\text { ogiwara/co }}{\underline{\text { vid19 }}}}$ & 885 & $\begin{array}{l}\text { less than } \\
1 \text { day }\end{array}$ & $\begin{array}{l}\text { Visual Dashboard } \\
\text { HTML }\end{array}$ & 109 & 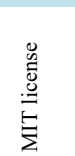 & $\begin{array}{l}\text { The state of the infection of the new coronavirus } \\
\text { (COVID19) in Japan was summarized visually } \\
\text { from a press release from the Ministry of Health, } \\
\text { Labor and Welfare. }\end{array}$ & - & 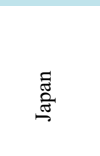 & \\
\hline
\end{tabular}




\begin{tabular}{|c|c|c|c|c|c|c|c|c|c|c|}
\hline & $\frac{\underline{\text { stevenliuyi// }}}{\underline{\text { covid19 }}}$ & 208 & $\begin{array}{l}\text { less than } \\
1 \text { day }\end{array}$ & $\begin{array}{l}\text { Visual Dashboard } \\
\text { JavaScript }\end{array}$ & 68 & 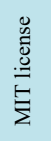 & $\begin{array}{l}\text { an animated and interactive map for COVID-19 } \\
\text { to track the outbreak over time by country and } \\
\text { other divisions in some selected countries }\end{array}$ & GIS analysis & हुّ & 畩 \\
\hline & $\begin{array}{l}\frac{\text { globalcitize }}{\text { n/2019- }} \\
\underline{\text { wuhan- }} \\
\frac{\text { coronavirus }}{\text {-data }}\end{array}$ & 618 & 22 days & $\begin{array}{l}\text { PHP } \\
\text { Visual Dashboard }\end{array}$ & 137 & 灾 & a data repository focused on china & $\begin{array}{l}\text { A public accessible COVID-19 data repository that visualize and } \\
\text { integrated view from various sources on the www based on the time. This } \\
\text { data will be useful to complementary analysis. }\end{array}$ & 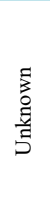 & $\frac{5}{\stackrel{2}{2}}$ \\
\hline \multirow{5}{*}{ 离 } & $\begin{array}{l}\underline{\text { nytimes/co }} \\
\text { vid-19-data }\end{array}$ & $4 \mathrm{k}$ & $\begin{array}{l}\text { less than } \\
1 \text { day }\end{array}$ & Open Dataset & $1.1 \mathrm{k}$ & & $\begin{array}{l}\text { A compiler that analysis New York Times time } \\
\text { series data from state and local divisions and } \\
\text { connected health departments to provide a } \\
\text { comprehensive profile of the ongoing outbreak }\end{array}$ & $\begin{array}{l}\text { A high volume of data on cumulative coronavirus cases and deaths were } \\
\text { published openness }\end{array}$ & 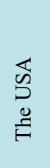 & $\frac{\sqrt[n]{2}}{2}$ \\
\hline & $\begin{array}{l}\frac{\text { BlankerL/D }}{\underline{\mathrm{XY}-}} \\
\frac{\text { COVID-19- }}{\underline{\text { Data }}}\end{array}$ & $1.4 \mathrm{k}$ & $\begin{array}{l}\text { less than } \\
1 \text { day }\end{array}$ & Python & 440 & 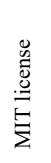 & $\begin{array}{l}\text { is the data warehouse to publish the latest data in } \\
\mathrm{CSV} \text { format, which can be easily processed and } \\
\text { loaded by most software }\end{array}$ & $\begin{array}{l}\text { providing a research oriented data warehouse for COVID-19 infection } \\
\text { time series }\end{array}$ & 䇛 & $\frac{\substack{2 \\
\frac{2}{2}}}{3}$ \\
\hline & $\frac{\text { pomber/cov }}{\underline{\mathrm{id} 19}}$ & 834 & $\begin{array}{c}\text { less than } \\
1 \text { day }\end{array}$ & $\begin{array}{l}\text { JSON } \\
\text { JavaScript } \\
\text { Messaging }\end{array}$ & 277 & & $\begin{array}{l}\text { JSON time-series of COVID-19 cases per } \\
\text { country }\end{array}$ & $\begin{array}{l}\text { Transforms the data from CSSEGISandData/COVID-19 into a JSON file } \\
\text { to automated parsing of data }\end{array}$ & $\begin{array}{l}\frac{\tilde{E}}{5} \\
\frac{0}{5} \\
\frac{5}{5}\end{array}$ & $\frac{\substack{2 \\
\frac{2}{2}}}{3}$ \\
\hline & $\frac{\underline{\text { datasets } / \text { co }}}{\underline{\text { vid-19 }}}$ & 546 & $\begin{array}{l}\text { less than } \\
1 \text { day }\end{array}$ & $\begin{array}{l}\text { Python } \\
\text { Open Dataset }\end{array}$ & 284 & 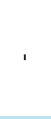 & COVID-19 time series data on cases & $\begin{array}{l}\text { This dataset includes time series data to track the number of cases } \\
\text { affected by COVID-19 worldwide }\end{array}$ & $\begin{array}{l}\frac{5}{5} \\
\frac{5}{5} \\
\frac{5}{5}\end{array}$ & 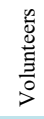 \\
\hline & $\frac{\text { AaronWard }}{\text { /covidify }}$ & 383 & 2 days & Jupiter Notebook & 100 & 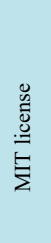 & $\begin{array}{l}\text { COVID-19 report and dataset generator developed } \\
\text { for python programming language }\end{array}$ & $\begin{array}{l}\text { Generate visualizations } \\
\text { Generate a time series dataset } \\
\text { Generate a daily stats dataset } \\
\text { Shows number of people currently infected Generates an excel report } \\
\text { including all of the above Forecast global and country confirmed cases } \\
\text { Filter by country List all countries affected }\end{array}$ & $\begin{array}{l}\tilde{E} \\
\frac{5}{5} \\
\frac{5}{5}\end{array}$ & $\frac{3}{\stackrel{2}{2}}$ \\
\hline 要 & $\begin{array}{l}\frac{\text { ieee } 8023 / \mathrm{co}}{\mathrm{vid-}} \\
\begin{array}{c}\underline{\text { chestxray- }} \\
\text { dataset }\end{array}\end{array}$ & $1.6 \mathrm{k}$ & $\begin{array}{l}\text { less than } \\
1 \text { day }\end{array}$ & $\begin{array}{l}\text { Python } \\
\text { Open Dataset }\end{array}$ & 434 & & $\begin{array}{l}\text { An open source database of COVID- } 19 \text { cases } \\
\text { involving chest X-ray and } \mathrm{CT} \text { images }\end{array}$ & $\begin{array}{l}\text { these images will be used to develop image processing and deep learning } \\
\text { based solutions to classify, detect, predict and analysis the infection }\end{array}$ & 吾 & 产 \\
\hline
\end{tabular}




\begin{tabular}{|c|c|c|c|c|c|c|c|c|c|}
\hline $\begin{array}{l}\frac{\text { lindawangg }}{\text { /COVID- }} \\
\underline{\text { Net }}\end{array}$ & 483 & $\begin{array}{c}\text { less than } \\
1 \text { day }\end{array}$ & $\begin{array}{l}\text { Python } \\
\text { Deep learning } \\
\text { image processing }\end{array}$ & 172 & 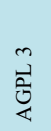 & $\begin{array}{l}\text { Was developed for faster interpretation of } \\
\text { radiography images }\end{array}$ & $\begin{array}{l}\text { Present COVID-Net, a deep convolutional neural network solution for the } \\
\text { detection of COVID-19 cases from radiography X-ray images that is open } \\
\text { source and available to the developers. }\end{array}$ & 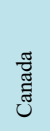 & 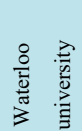 \\
\hline$\frac{\underline{\text { elcronos} / \mathrm{C}}}{\underline{\text { OVID-19 }}}$ & 318 & 4 days & $\begin{array}{l}\text { Deep learning } \\
\text { Image analysis }\end{array}$ & 78 & 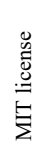 & $\begin{array}{l}\text { COVID-19 identification and diagnosis from } x- \\
\text { rays images using machine Vision and Deep } \\
\text { Learning }\end{array}$ & $\begin{array}{l}\text { Developing an accurate decision support model to diagnosis COVID-19 } \\
\text { from medical images. }\end{array}$ & 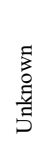 & 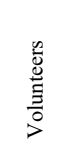 \\
\hline$\frac{\underline{\mathrm{UCSD}-}}{\underline{\mathrm{AI} 4 \mathrm{H} / \mathrm{COV}}}$ & 314 & 3 days & Open Dataset & 90 & & $\begin{array}{l}\text { The COVID-CT-Dataset has } 349 \mathrm{CT} \text { images } \\
\text { containing clinical symptoms and findings of } \\
\text { COVID-19 }\end{array}$ & $\begin{array}{l}\text { The CT images are collected from COVID19-related published or preprint } \\
\text { articles from databases such as medRxiv NEJM, JAMA, bioRxiv, Lancet } \\
\text { and etc. images containing COVID-19 related symptoms and signs are } \\
\text { selected by parsing the images caption in the documents. The primary goal } \\
\text { of the dataset is the artificial intelligence and machine learning. }\end{array}$ & , & \\
\hline$\frac{\frac{\text { Pratitya/CO }}{\text { VID-19- }}}{\text { timeline }}$ & $1.7 \mathrm{k}$ & $\begin{array}{c}\text { less than } \\
1 \text { day }\end{array}$ & $\begin{array}{l}\text { Open dataset (media, news, } \\
\text { etc.) }\end{array}$ & 293 & & $\begin{array}{l}\text { The timeline sorted out the official media } \\
\text { information as the classics, the private media and } \\
\text { the self-media as the latitude, and the matter of } \\
\text { the day, focusing on the spread of the epidemic } \\
\text { and the field of public opinion, trying to present } \\
\text { the beginning and end of the COVID }\end{array}$ & media repository for NLP and crawling & 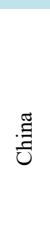 & 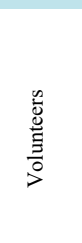 \\
\hline 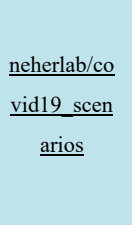 & 962 & $\begin{array}{c}\text { less than } \\
1 \text { day }\end{array}$ & $\begin{array}{l}\text { Visual Interface } \\
\text { Analytical tool } \\
\text { Scenario Simulation } \\
\text { based on SIR model } \\
\text { Typescript }\end{array}$ & 238 & 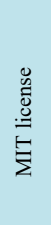 & $\begin{array}{l}\text { This tool is based on the Susceptible, Infectious, } \\
\text { or Recovered (SIR) model that can forecast and } \\
\text { simulate an infection outbreak such as COVID19. }\end{array}$ & $\begin{array}{l}\text { to investigate the dynamic behaviors of COVID-19 cases and the } \\
\text { associated strain on the health system in the ongoing future }\end{array}$ & 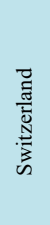 & 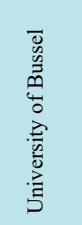 \\
\hline $\begin{array}{l}\frac{\text { ImperialCol }}{\text { legeLondon }} \\
\frac{\text { /covid19mo }}{\text { del }}\end{array}$ & 523 & & $\begin{array}{l}\text { Jupiter Notebook } \\
\text { Bayesian Model }\end{array}$ & 132 & 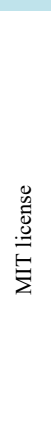 & $\begin{array}{l}\text { A collection of codes for modeling and predicting } \\
\text { estimated deaths and cases for COVID19 from } \\
\text { Report } 13 \text { published by MRC Centre for Global } \\
\text { Infectious Disease Analysis, Imperial College } \\
\text { London } \\
\text { The model includes three components as follow: } \\
\text { 1)population saturation effects, 2) prior } \\
\text { uncertainty on the infection fatality ratio and 3) a } \\
\text { more balanced prior on intervention effects. They } \\
\text { also included another countries (for example, } \\
\text { Greece, Netherlands and Portugal) }\end{array}$ & $\begin{array}{l}\text { Modeling estimated deaths and cases for COVID19. } \\
\text { The model can estimate the number of infections and the impact of non- } \\
\text { pharmaceutical interventions on infection control. }\end{array}$ & 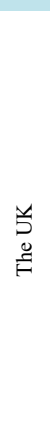 & 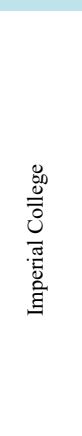 \\
\hline
\end{tabular}




\begin{tabular}{|c|c|c|c|c|c|c|c|c|c|c|}
\hline & $\frac{\text { CodeForPhi }}{\underline{\text { ly/chime }}}$ & 166 & $\begin{array}{l}\text { less than } \\
1 \text { day }\end{array}$ & $\begin{array}{l}\text { Python } \\
\text { Epidemiological } \\
\text { model(S//R) }\end{array}$ & 129 & 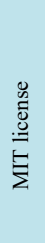 & $\begin{array}{l}\text { The project empowers capacity planning by } \\
\text { estimating and predicting of total new and running } \\
\text { daily inpatient hospitalizations, ICU admissions, } \\
\text { and number of ventilation needs. In the behind the } \\
\text { scene, a SIR model was developed to generate } \\
\text { estimated data. }\end{array}$ & $\begin{array}{l}\text { The aim of the project is to help healthcare centers by an accurate } \\
\text { estimation of hospital capacity needs in the Covid-19 era }\end{array}$ & $\begin{array}{l}\text { है } \\
\text { D } \\
\text { ह } \\
\text { है }\end{array}$ & 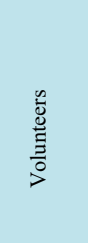 \\
\hline \multirow{7}{*}{ 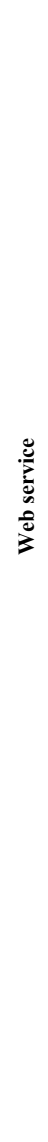 } & $\frac{\text { NovelCOV }}{\underline{\text { ID/API }}}$ & $1.6 \mathrm{k}$ & $\begin{array}{l}\text { less than } \\
1 \text { day }\end{array}$ & $\begin{array}{l}\text { JavaScript } \\
\text { collaborative environment }\end{array}$ & 432 & $\begin{array}{l}\stackrel{\dot{m}}{\overrightarrow{0}} \\
\dot{\overrightarrow{0}}\end{array}$ & $\begin{array}{l}\text { A well-designed API for Current cases and related } \\
\text { statistics about COVID-19 }\end{array}$ & $\begin{array}{l}\text { Provides an API for programmers and data scientists to call online data by } \\
\text { programming in their research and projects. }\end{array}$ & $\begin{array}{l}\text { ह } \\
\text { 章 } \\
5\end{array}$ & 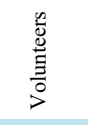 \\
\hline & $\begin{array}{l}\frac{\text { BlankerL/D }}{\text { XY- }} \\
\text { COVID-19- } \\
\underline{\text { Crawler }}\end{array}$ & $1.5 \mathrm{k}$ & 2 days & Python API & 315 & 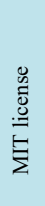 & $\begin{array}{l}\text { COVID-19/2019-nCoV infection data realtime } \\
\text { crawler } \\
\text { The deployed crawler will crawls the data every } \\
\text { minutes, stores them into MongoDB, and saves all } \\
\text { historical data updates }\end{array}$ & provide a fully Free COVID-19 data API & 苞 & I \\
\hline & $\begin{array}{l}\underline{\text { soroushche }} \\
\text { hresa/awes } \\
\text { ome- } \\
\text { coronavirus }\end{array}$ & 945 & $\begin{array}{l}\text { less than } \\
1 \text { day }\end{array}$ & JavaScript & 259 & $\begin{array}{l}\mathscr{.} \\
\stackrel{.}{\Xi} \\
\stackrel{. \Xi}{\Xi}\end{array}$ & $\begin{array}{l}\text { A list of useful projects and resources for } \\
\text { COVID-19 }\end{array}$ & Presenting a unique list of related projects & $\begin{array}{l}\text { ह } \\
\text { D } \\
\text { E } \\
\text { ह }\end{array}$ & 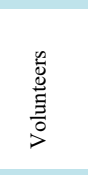 \\
\hline & $\begin{array}{l}\underline{\text { mathdroid/c }} \\
\underline{\text { ovid-19-api }}\end{array}$ & 878 & 3 days & $\begin{array}{l}\text { JSON } \\
\text { Typescript }\end{array}$ & 169 & ' & $\begin{array}{l}\text { Serving data from John Hopkins University as a } \\
\text { JSON API }\end{array}$ & A easy to use web service to capture updated COVID-19 data & $\begin{array}{l}\text { है } \\
\text { D } \\
\text { ह } \\
\text { है }\end{array}$ & 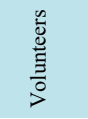 \\
\hline & $\begin{array}{l}\text { gcreddy } 42 / \\
\underline{\text { hiring2020 }}\end{array}$ & 632 & 1 day & HTML List & 169 & . & A list of Internship Status in COVID-19 age & $\begin{array}{l}\text { Inform people about active or deactivate internship programs in } \\
\text { companies. }\end{array}$ & $\begin{array}{l}\text { ह } \\
\text { D } \\
\text { 站 } \\
\end{array}$ & 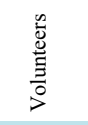 \\
\hline & $\begin{array}{c}\begin{array}{c}\text { midas- } \\
\text { network/C }\end{array} \\
\underline{\text { OVID-19 }}\end{array}$ & 551 & $\begin{array}{l}\text { less than } \\
1 \text { day }\end{array}$ & Tex & 177 & . & $\begin{array}{l}\text { An interactive repository to share computable and } \\
\text { standard format of spreadsheet data( CSV) } \\
\text { including original data, parameter estimates, } \\
\text { software, and metadata }\end{array}$ & $\begin{array}{l}\text { This repository can play a role as a central platform to share ease to use } \\
\text { data formats relevant for modeling of the COVID-19 outbreak }\end{array}$ & $\underset{s}{n}$ & 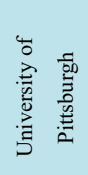 \\
\hline & $\begin{array}{l}\frac{\text { phildini/sta }}{\text { yinghomecl }} \\
\underline{\mathrm{ub}}\end{array}$ & 453 & $\begin{array}{l}\text { less than } \\
1 \text { day }\end{array}$ & $\begin{array}{l}\text { Ruby } \\
\text { Web based content } \\
\text { management }\end{array}$ & $1.2 \mathrm{k}$ & 8 & $\begin{array}{l}\text { An up to date list of all the events, universities, } \\
\text { and companies WFH or events changed because } \\
\text { of covid-19 }\end{array}$ & $\begin{array}{l}\text { Provide a running list of events, universities, and companies that are } \\
\text { taking steps to address the spread of COVID-19 }\end{array}$ & 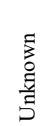 & 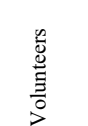 \\
\hline
\end{tabular}




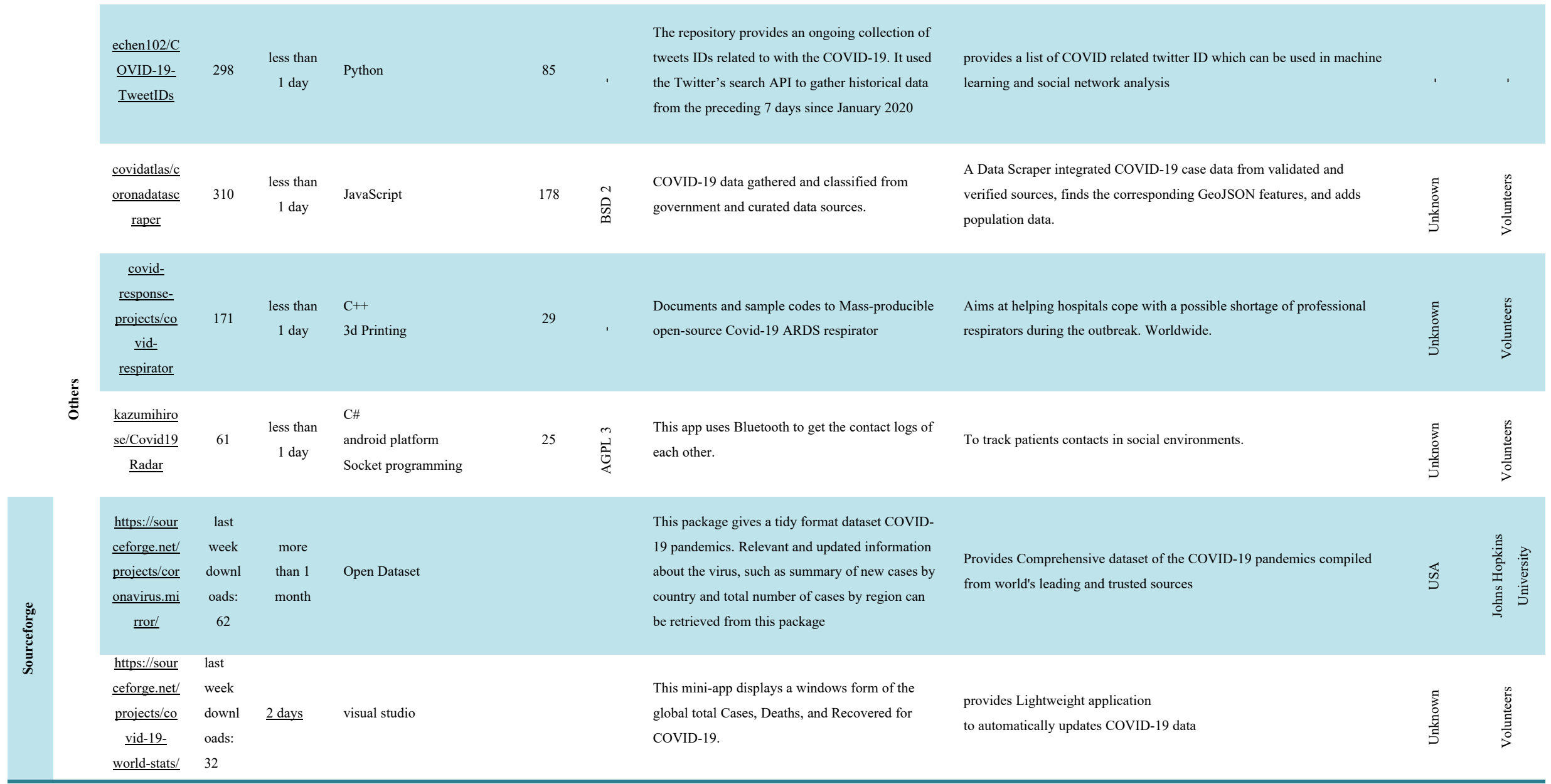




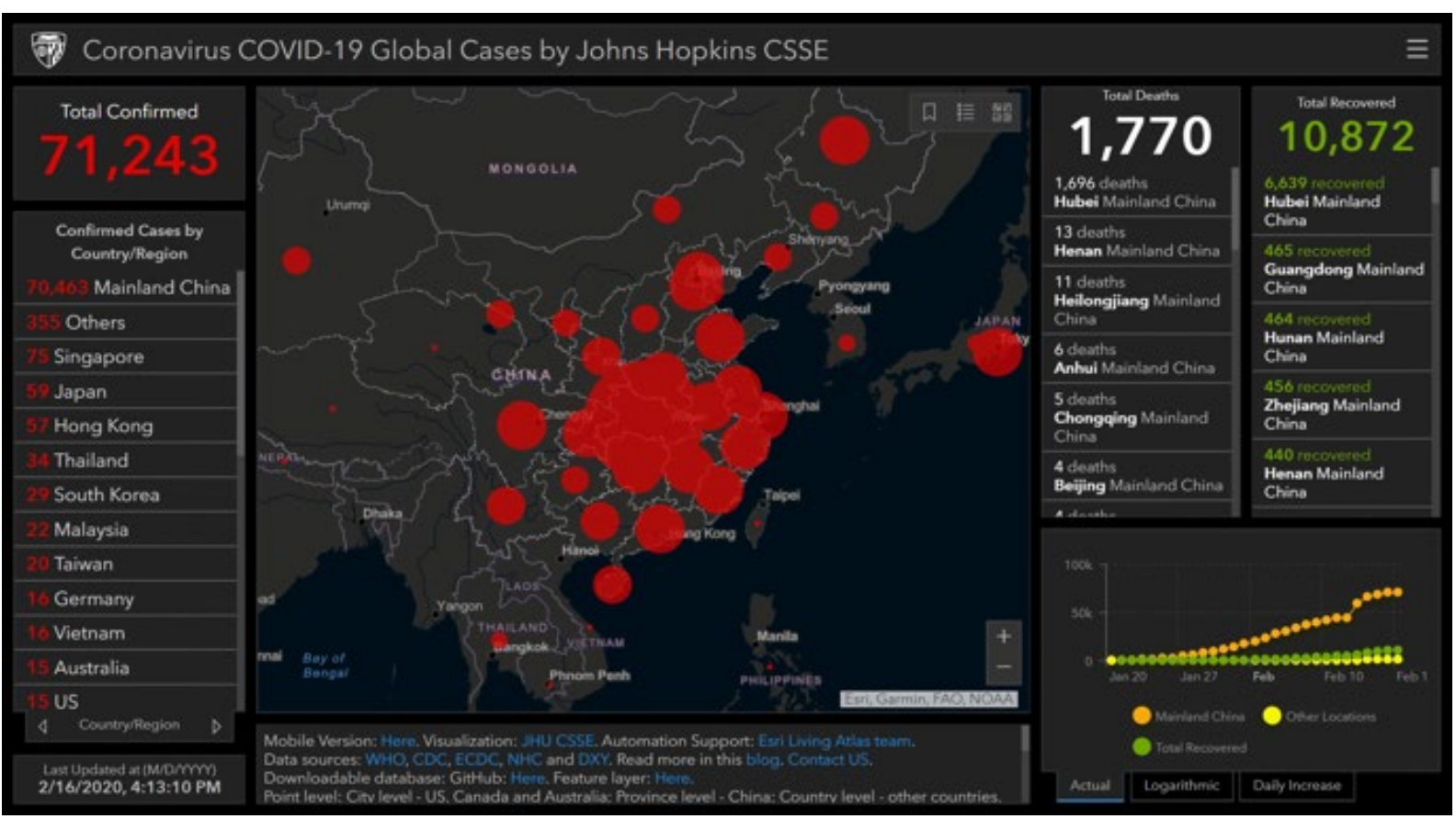

Figure 2. JHU CSSE. Screenshot date: 16 February 2020 (15)

\section{Discussion}

The current review aimed to investigate the use of FOSS against COVID-19 available through GitHub and SourceForge. The 40 projects included in the review encompassed five different scopes, including Business Intelligence and Visual Dashboards, TimeSeries, Artificial Intelligence, Epidemiological Approaches, and Web Services.

\section{Business intelligence and visual dashboards}

Business intelligence (BI) is a platform covering all information systems (IS) committed to providing decision support by collecting and aggregating raw data obtained from the operating systems. BI tools, such as dashboards, are an essential method of data visualization for presenting a visual overview of information to facilitate new usable viewpoints to improve decision-making or management (13). A dashboard offers a means for various visual elements to view and interpret information promptly. They can also save time and money when making decisions, provided that a dashboard can synthesize many details (14). When diseases can be transmitted so quickly, knowledge needs to move even more quickly. Here, map-based dashboards are becoming crucial (15). Most of the software in the present review utilizes the dashboard.

For example, in "CSSEGISandData/COVID-19", which has the highest stargazers $(20.2 \mathrm{k})$ and forks $(10.9 \mathrm{k})$, the dashboard is used in real-time to imagine and monitor confirmed cases of COVID-19. The report, which was first publicly released on January 22, highlights the position and number of reported COVID-19 cases, deaths, and recoveries for all affected countries. It has been developed to provide a user-friendly resource for researchers, public health officials, and the public to monitor the outbreak as it unfolds. The dashboard, which was created by Lauren Gardner (an epidemiologist) and her JHU CSSE team (the Center for Systems Science and Engineering (CSSE) at Johns Hopkins University (JHU)), went viral with hundreds of news articles and social media shares. This strong response to the JHU CSSE and other dashboards signifies individuals' willingness to monitor health threats. Anyone with Internet access can gain a vast amount of knowledge about COVID-19 in just a few clicks (Figure 2)

\section{Time-series}

A time-series is a set of observations that are uniformly distributed over time or over a certain other metameter. Data on the time-series are created naturally when a population or other phenomenon is monitored over time. A major goal in public health and biomedical science is to understand how explanatory variables affect an outcome over time. Experience with the use of time-series in monitoring population health during outbreaks of infectious diseases, such as SARS, Ebola, and seasonal influenza, has been demonstrated in various studies (16-21). The software reviewed in this study shows that time-series can be used for various purposes to control the COVID-19 disease. In "nytimes/covid-19-data," New York Times data are collected from state and local governments, while health ministries are working to fully monitor the ongoing outbreak (Figure 3). Data are used for mapping and tracking reports of outbreaks. Such data will be made available to the public in response to requests from researchers, scientists, and government officials who wish to have access to the data to better understand the outbreak. 


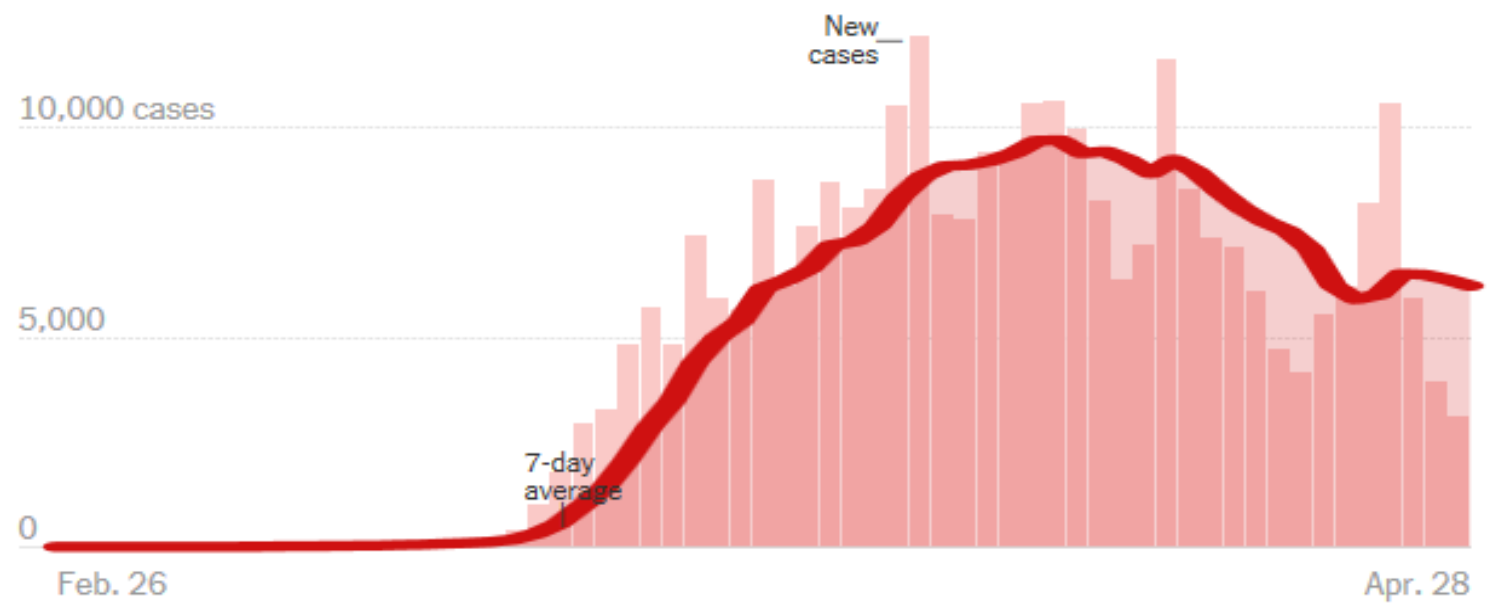

Figure 3. New reported cases by day in New York

S C E N A RIO

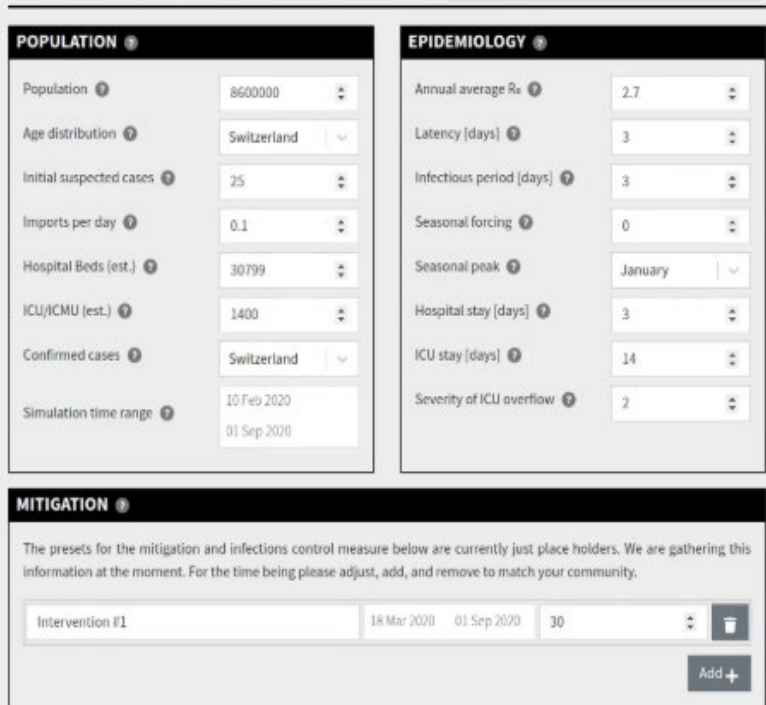

\section{AGE-GROUP-SPECIFIC PARAMETERS
Demmographics, disease severity, group-specific isolation}

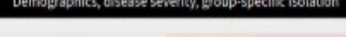

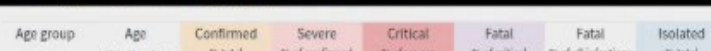

0.9 distribution soid

$\begin{array}{rr}10-19 & 854566 \\ 20-29 & 1039727\end{array}$

10.39 $\quad 1219227$

10-49 $\quad 1165590$

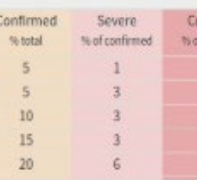

Figure 4. COVID-19 model outbreak trajectories and hospital demand

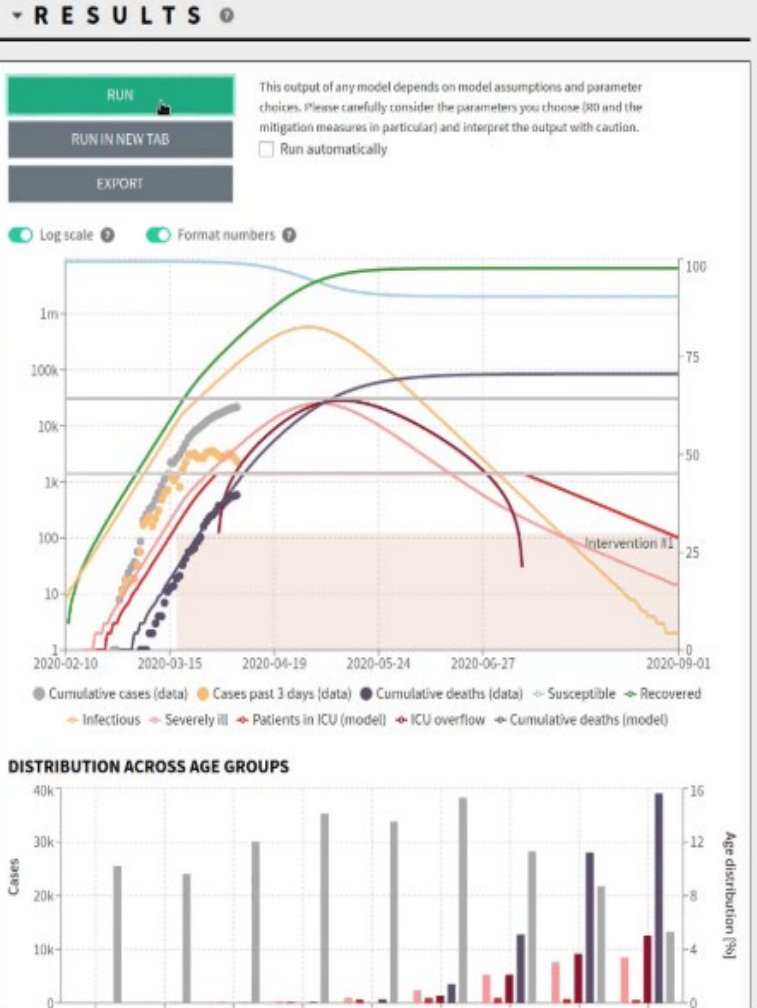

\section{Artificial Intelligence}

As a non-invasive imaging technique, computed tomography (CT) can detect characteristic manifestations in the COVID-19-associated lung and is recommended as the primary evidence for clinically diagnosed cases in this epidemic in Hubei, China. The software utilized in this study used artificial intelligence techniques and tomography images to detect COVID-19 $(22,23)$. Artificial intelligence refers to any machine that exhibits human mind-related characteristics, such as thinking and problem-solving
(24). In computer science, different branches of artificial intelligence are used, some of which include machine learning, neural networks, machine vision, expert system, and genetic algorithm (25). The "ieee8023/covid-chestxray-dataset" developers want to improve triage prognoses and control COVID-19 patient treatment. It would give physicians an advantage and allow them to behave with greater trust when waiting for a radiologist's report by having a digital second opinion to validate their evaluation of a patient's condition. Such instruments can also include 
objective ratings that can be considered and used in studies. In another project, "lindawangg/COVID-Net," the University of Waterloo has developed a deep convolutional neural network designed to detect COVID-19 cases from chest X-ray images, which are open-source and available to the general public. COVID-Net makes predictions using a method of interpretation to gain greater insight into the crucial factors associated with COVID-19 cases, which can help clinicians enhance screening, as well as increase trust and clarity by using COVID-Net for accelerated computer-aided screening (26).

\section{Epidemiological approaches}

Epidemiology is the study of the distribution and scale of disease-related problems in human populations. In particular, it deals with the detection of etiological factors in disease pathogenesis and the collection of important data for the management, assessment, and preparation of disease prevention, control, and treatment services (27). In epidemiological studies, approaches such as simulation models, distribution maps, mortality estimates, forecasts, etc. are used $(28,29)$. The "neherlab/covid19 scenarios" project simulates a COVID-19 outbreak. The primary aim of the project is to analyze in the near future complexities of COVID-19 cases and the resulting strain on the healthcare system. The outbreak is affected by interventions to monitor infection, such as closures of schools, lockdowns, etc. By changing the mitigation parameters, the impact of these steps can be integrated into the simulation (Figure 4). Also, the numbers of deaths and infections and the effects of non-pharmaceutical treatments are documented in the "ImperialCollegeLondon/covid19model" project, COVID-19 modeling.

\section{Web Service}

A web service is a set of open protocols and standards that are commonly used to share data between applications or systems. In healthcare, the web services model offers a perfect platform to solve challenging interoperability issues. Web services are designed to wrap and display existing resources, and also provide interoperability between different applications (30). Web services can expand healthcare enterprises through the delivery of their own services to others (31). They can also prolong the life of existing applications by improving the accessibility of previously proprietary functions as web services (32). Almost any web service is an Application Programming Interface (API). API is a software interface allowing two programs to communicate without any user interaction (33). Regarding the reviewed software, the "BlankerL/DXY-COVID-19Crawler" provides a completely free API of COVID19 information. The deployed crawler will crawl the data every minute, store it in MongoDB, and save all updates of historic data. Backtracking the disease may be beneficial in the future. Other projects provide services such as a list of COVID-19-related tweets, running list of events, sharing computable files with data, parameter estimates, and metadata.

Both SourceForge applications display a dataset of global total COVID-19 cases (Figure 5).

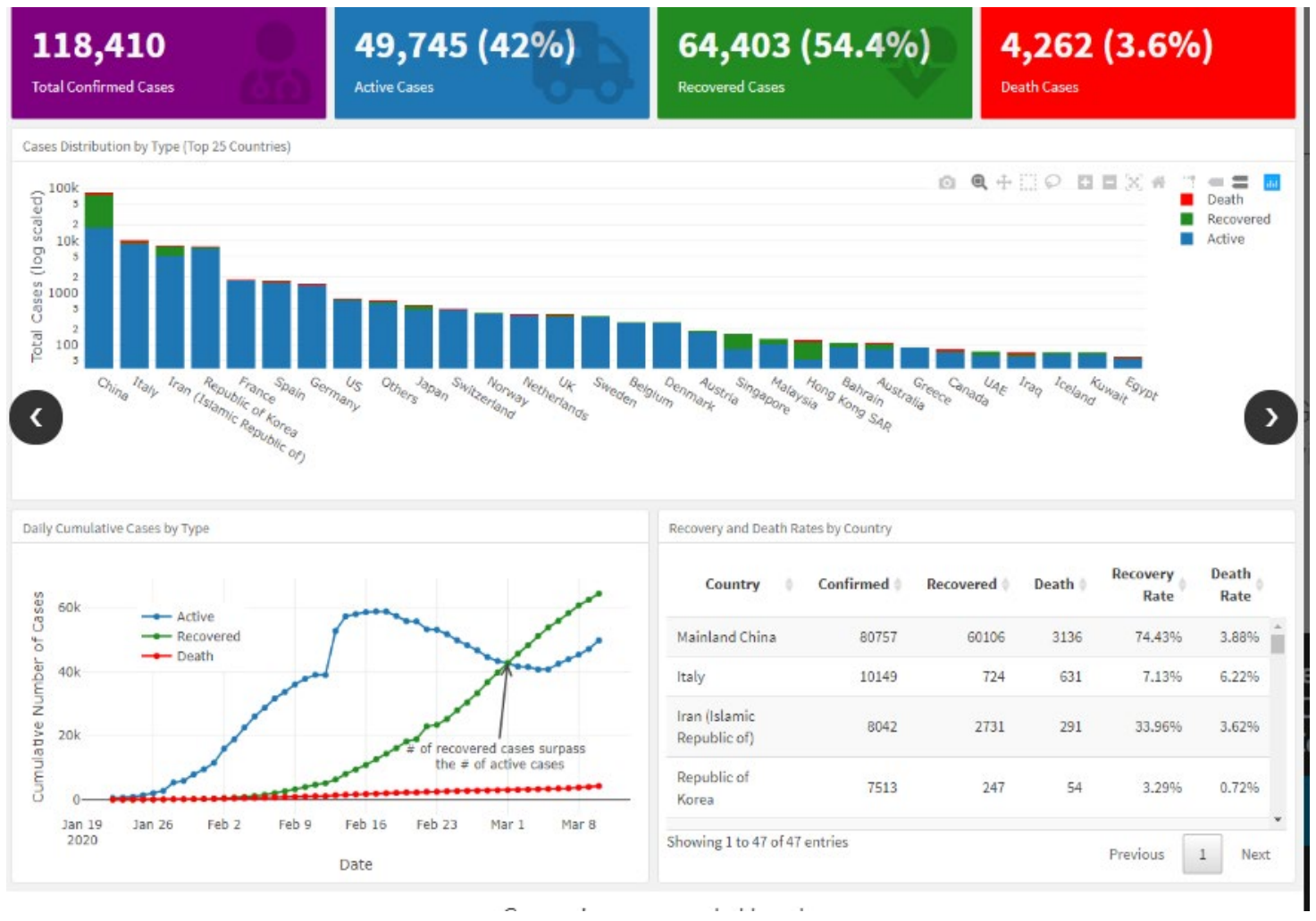

Figure 5. The screenshot of "https://sourceforge.net/projects/coronavirus.mirror/" 


\section{Conclusion}

During previous epidemics (Ebola and SARS), opensource software helped combat one of the most deadly pandemics in recent days. Using such software will save a great deal of time and money, and it can be useful for global organizations. Our results were limited to new repositories. Older projects related to the long-term support condition customized to COVID-19, such as Ushahidi, were not discussed in the current paper, even though they focused on similar topics. Previously learned lessons from FOSS have shown that the explained projects would play important roles in future epidemics by forking and joining in new projects, Which cover specific events and disasters

\section{Acknowledgments}

We would like to express our gratitude to the sanamsahand.com for sharing their pearls of wisdom with us during the course of this research.

\section{Ethical considerations}

Ethical issues (Including plagiarism, informed consent, misconduct, data fabrication and/or falsification, double publication and/or submission, redundancy, etc.) have been completely observed by the authors.

\section{Funding and support}

This research resulted from an independent research without receiving any financial support.

\section{Conflict of Interest}

Authors declared no conflict of interest.

\section{References}

1. Xia W, Shao J, Guo Y, Peng X, Li Z, Hu D. Clinical and CT features in pediatric patients with COVID19 infection: Different points from adults. Pediatr Pulmonol.2020; $\quad$ 55(5): $\quad$ 1169-74 [DOI:10.1002/ppul.24718]

2. Organization WHO. Novel Coronavirus (2019$\mathrm{nCoV}$ ) situation reports. 2020.

3. Smith N, Fraser M. Straining the system: novel coronavirus (COVID-19) and preparedness for concomitant disasters. Am Pub Health Assoc; 2020; 110(5):648-49. [DOI:10.2105/AJPH.2020.305618]

4. Galaz V. Pandemic 2.0: Can information technology help save the planet? Sci Policy Sustain Develop. 2009;51(6):20-28 [DOI:10.1080/00139150903337225]

5. Xie B, He D, Mercer T, et al. Global health crises are also information crises: A call to action. J Assoc
Inform Sci Technol. 2020. 10.1002/asi.24357 [DOI:10.1002/asi.24357]

6. Yavlinsky A, Lule SA, Burns R, et al. Mobilebased and open-source case detection and infectious disease outbreak management systems: a review. Wellcome Open Research. 2020;5(37):37. [DOI:10.12688/wellcomeopenres.15723.1]

7. Li P. Investigating information technologies in disasters: Three essays on micro-blogging and free and open source software (foss) environment: Faculty of the Graduate School of the University at Buffalo, State; 2011.

8. De Silva C, Prustalis M. The sahana free and open source disaster management system in haiti. ICT for Disaster Risk Reduction, ICT Case Study. 2010.

9. Tom-Aba D, Olaleye A, Olayinka AT, et al. Innovative technological approach to Ebola virus disease outbreak response in Nigeria using the open data kit and form hub technology. PloS One. 2015;10(6):e0131000-e.

[DOI:10.1371/journal.pone.0131000]

10. Ansumana R, Bonwitt J, Stenger DA, Jacobsen KH. Ebola in Sierra Leone: a call for action. The Lancet. 2014;384(9940):303. [DOI:10.1016/S01406736(14)61119-3]

11. STEM: An open source tool for disease modeling. Health Secur. 2019;17(4):291-306. [DOI:10.1089/hs.2019.0018]

12. Tiemann M, Initiative POS. How open source software can save the ICT industry one trillion dollars per year. 2009;3:2009.

13. Iftikhar A, Bond R, McGilligan V, et al. Role of dashboards in improving decision making in healthcare: Review of the literature. Proceedings of the 31 st European Conference on Cognitive Ergonomics; 2019. [DOI:10.1145/3335082.3335109]

14. Maheshwari D, Janssen M. Dashboards for supporting organizational development: principles for the design and development of public sector performance dashboards. proceedings of the 8th international conference on theory and practice of electronic governance; 2014. [DOI:10.1145/2691195.2691224]

15. Boulos MNK, Geraghty EM. Geographical tracking and mapping of coronavirus disease COVID-19/severe acute respiratory syndrome coronavirus 2 (SARS-CoV-2) epidemic and associated events around the world: how 21st century GIS technologies are supporting the global fight against outbreaks and epidemics. BioMed Central; 2020. [DOI:10.1186/s12942-020-002028]

16. Lai D. Monitoring the SARS epidemic in China: a time series analysis. J Data Sci. 2005;3(3):279-93. 
17. Chang HJ, Huang N, Lee CH, Hsu YJ, Hsieh CJ, Chou YJ. The impact of the SARS epidemic on the utilization of medical services: SARS and the fear of SARS. Am J Pub Health. 2004;94(4):562-4. [DOI:10.2105/AJPH.94.4.562]

18. Warren-Gash C, Bhaskaran K, Hayward A, et al. Circulating influenza virus, climatic factors, and acute myocardial infarction: a time series study in England and Wales and Hong Kong. J Infect Diseases. 2011;203(12):1710-8. [DOI:10.1093/infdis/jir171]

19. Upshur R, Knight K, Goel V. Time-series analysis of the relation between influenza virus and hospital admissions of the elderly in Ontario, Canada, for pneumonia, chronic lung disease, and congestive heart failure. Am J Epidemiol. 1999;149(1):85-92. [DOI:10.1093/oxfordjournals.aje.a009731]

20. Lekone PE, Finkenstädt BF. Statistical inference in a stochastic epidemic SEIR model with control intervention: Ebola as a case study. Biometrics. 2006;62(4):1170-7. 0420.2006.00609.x

21. Camacho A, Kucharski A, Funk S, Breman J, Piot $\mathrm{P}$, Edmunds W. Potential for large outbreaks of Ebola virus disease. Epidemics. 2014;9:70-8. [DOI:10.1016/j.epidem.2014.09.003]

22. Bernheim A, Mei X, Huang M, et al. Chest CT findings in coronavirus disease-19 (COVID-19): relationship to duration of infection. Radiol. 2020:200463. [DOI:10.1148/radiol.2020200463]

23. Li Y, Xia L. Coronavirus disease 2019 (COVID$19)$ : role of chest $C T$ in diagnosis and management. Am J Roentgenol. 2020:1-7. [DOI:10.2214/AJR.20.22954]

24. Korb KB, Nicholson AE. Bayesian artificial intelligence: $\quad$ CRC press; 2010. [DOI:10.1201/b10391]

25. Hajiali M. Big data and sentiment analysis: A comprehensive and systematic literature review. Concurr Comput Pract Exper.32(14):e5671 [DOI:10.1002/cpe.5671]

\section{How to Cite This Article:}

26. Wang L, Wong A. COVID-Net: A tailored deep convolutional neural network design for detection of COVID-19 cases from chest radiography images. arXiv preprint arXiv:200309871. 2020.

27. Thrusfield M. Veterinary epidemiology: John Wiley \& Sons; 2018.

28. Cruz-Gomes S, Amorim-Lopes M, Almada-Lobo B. Epidemiology and demand for healthcare: an agent-based simulation model. Abstracts Booklet of IEMS'19: 10th Industrial Engineering and Management Symposium: The Impact of DEGI Research on Society; 2019.

29. Siswanto S, Risva R, Nana M. Epidemiology forecasting analysis of dengue haemorraghic fever with seasonal autoregressive integrated moving average in tropical area.Pub Health Indonesia.2019;5(2):38-45 [DOI:10.36685/phi.v5i2.261]

30. Subbulakshmi S, Krishnan A, Sreereshmi R, editors. Contextual aware dynamic healthcare service composition based on semantic web ontology. 2019 2nd International Conference on Intelligent Computing, Instrumentation and Control Technologies (ICICICT); 2019: IEEE. [DOI:10.1109/ICICICT46008.2019.8993303]

31. Leatherman S, Tawfik L, Jaff D, et al. Quality health care in extreme adversity-an action framework. Int $\mathrm{J}$ Qual Health Care.2019; 31(9):G133-G135. [DOI:10.1093/intqhe/mzz066]

32. Hanen J, Kechaou Z, Ayed MB. An enhanced healthcare system in mobile cloud computing environment. Vietnam J Computer Science. 2016;3(4):267-77. [DOI:10.1007/s40595-0160076-y]

33. Bott R. Methods and systems for providing application programming interfaces and application programming interface extensions to third party applications for optimizing and minimizing application traffic. Google Patents; 2019. 